\title{
Mito y utopía en la modernidad
}

\section{Introducción}

A muchos todavía les suena extraño que se hable de la presencia y operativización (política y social) del mito en la modernidad. Se nos ha enseñado que, justamente, modernidad significa progreso, apertura al futuro, utopía..., mientras que lo mítico haría referencia al pasado, a una visión circular de lo real que permanentemente estaría remitiéndose a los orígenes. El pensamiento mítico sería algo propio de pueblos primitivos (=premodernos); por consiguiente, sería algo ya superado en estos tiempos no sólo modernos, sino postmodernos.

No cabe duda que esa forma de entender la modernidad no es en absoluto descabellada: la modernidad se nutre del pensamiento biblico en el que se reivindica a un Dios - que a diferencia de otros dioses orientales- se revela (revela su poder y su bondad) en la marcha histórica que su pueblo realiza hacia su liberación: la frase "yo seré el que seré"I con que Yahvé responde a Moisés cuando este le pide revelarle su nombre expresa bien el carácter de este dios que mira hacia el futuro, es decir, de ese dios no dado de una vez y por siempre, sino que se va realizando él mismo en la medida en que su pueblo también lo hace. La modernidad, al nutrirse del pensamiento bßblico - vetero y neotestamentario-, asume la noción de progreso y de apertura histórica hacia el futuro que caracteriza al cristianismo.

En una palabra, podemos decir que la modernidad -al asumir el legado cristiano- se convierte en una cultura intrínsecamente utópica y abierta al futuro. Con ésto, evidentemente, no se está apuntando nada nuevo. La novedoso está en lo siguiente: en afirmar que la modernidad no sólo se nutre del cristianismo, sino también de elementos socio-culturales de carácter mítico. Al hacer esta afirmación, estaríamos diciendo que la modernidad no sólo es intrínsecamente utópica (progresiva y abierla al futuro), sino que es también intrínsecamente mf́tica (referida hacia los orígenes).

Ahora bien: $i$ de dónde provienen históricamente las formas míticas constitutivas de la modernidad? ¿En qué se diferencia el pensamiento cristiano del pensamiento mítico? ¿Qué es lo especifico de cada uno de ellos? ¿Cómo se insertan 
en la historia de occidente? Para avanzar una respuesta tentativa a estas preguntas nos remiliremos a los estudios clásicos que sobre el cristianismo y el pensamiento mítico efectuaron, desde la teología, R. Bultmann y W. Pannenberg2. A partir de la discusión entre estos autores intentaremos elaborar una reflexión más particular en torno al por qué de la presencia del mito en la modertiidad.

\section{Cristianismo y mito: las tesis de R. Bultmann y W. Pannenberg}

a) El mito como lo "pre-científico": $R$. Bultmann. El mito es, de alguna forma, una visión explicativa de la realidad. Para algunos pensadores, como el teólogo alemán Rudolf Bultmann, el mito es una explicación pre-científica. Por consiguiente, el mito sería una visión de la realidad elaborada por grupos humanos primitivos que no habrían alcanzado todavia un estadio científico en el conocimiento de la realidad.

"El lenguaje mítico consiste en hablar mundanamente de lo no-mundano, en hablar humanamente de lo divino. Correlativamente lo divino aparece mezclado con lo humano y se convierte en la explicación de los fenómenos naturales y temporales. Ya desde Heyne este pensamiento mítico se ve caracterizado y exigido por tres notas que le distinguen del pensamiento maduro: (1) una inadecuada intuición de las verdaderas causas de los fenómenos naturales y psíquicos; (2) una incapacidad para el pensamiento abstracto; y (3) la impresionabilidad a través de las sensaciones"3.

El pensamiento mítico es, en este sentido, un pensamiento ingenuo e inmaduro. Es un pensamiento que se remite a los dioses para explicar lo que acontece a los hombres: la voluntad de los dioses juega el papel de explicación causal de los fenómenos humanos. Asimismo, el pensamiento mítico es un pensamiento dualista: el mundo está formado por dos ordenes de realidad: el orden divino dividido, a su vez, en el orden de los dioses buenos que habitan el cielo y el orden de los dioses demonlacos que habitan el infierno- y el orden humano. De estos dos órdenes, el primero es causa del segundo, que es efecto de aquél. Este dualismo atraviesa la realidad del hombre:

"Naturalmente que en esta visión mítica del mundo se quiere expresar una profunda visión antropológica: el hombre es un ser relacional, sujeto a poderes externos a él, Dios o los dioses en el cielo y los poderes demonfacos en el infierno, que explicarlan la ambigüedad de la experiencia del hombre. Pero esta intuición antropologica es expresada en un concepto precientffico de naturaleza, como si cielo, tierra e infiemo fuesen cualitativamente distintos"4.

Lo importante para nosotros aquí es que para Bultmann el mito es algo precientifico. Por tanto, el mito es algo negativo que hay que superar. $\mathbf{Y}$ esa superación se realiza por la vla del pensamiento cientifico. "Resumiendo, el 
concepto de mito que tiene Bultmann es en su aspecto negativo el de narraciones que no han llegado a la madurez del pensamiento científico. Correspondientemente el proceso de desmitificación consiste en aceptar ese pensamiento científico e interpretar lo mitico existencialmente"s.

b) El mito como legitimación de los "orígenes": W. Pannenberg. Si pensadores como R. Bultmann contraponen el mito a la ciencia, hay otros, como W. Pannenberg - también té́logo-, que plantean el problema del mito desde una perspectiva distinta: Pannenberg no contrapone el mito a la ciencia, lo precientífico a lo científico, sino que contrapone mito y futuro, explicación mitológica y explicación utópica.

"El pensamiento mítico está relacionado con el tiempo primigenio (Urzeit) y con el orden que este fundamenta. Una manera de delimitarlo desde el punto de vista de la historia de las religiones consiste en diferenciarlo de géneros literarios como las "fábulas" y las "leyendas". Las fábulas son narraciones que no reclaman para sí ningún carácter histórico, mientras que las leyendas son narraciones que se entienden como históricas, pero que no tienen un carácter fundamentante"6.

Dos ideas claves en el texto citado son, primero, que el pensamiento mítico está relacionado con el tiempo primigenio $y$, segundo, que en ese tiempo primigenio hay algo fundamentante de lo existente. Es decir, el mito "tiene como contenido en el tiempo primigenio, en el 'principio' del orden presente un acontecimiento que constituye este orden presente de ahora y en ello muestra su fuerza perdurable"7. En este sentido, el mito se ocupa de ese "acontecimiento" del tiempo primigenio - de los orígenes- que constituye y fundamenta el orden presente. "El mito tiene por tanto dos caracteristicas: 1) narra un "hecho" que ocurre en el tiempo primigenio, y 2) por ocurrir en el tiempo primigenio tiene un carácter fundamentante para todo el orden de la vida" 8.

El orden presente no tiene sentido si no es por su remision a ese hecho primigenio que lo fundamenta: el mito quiere legitimar (J. Sobrino), no explicar, ese acontecimiento originario, cuya irrupción se celebra y renueva simbolicamente en el culto. "El mito, por tanto, no es como la 'etiología' la búsqueda de la explicación de un uso presente en el origen, sino es su legitimación. El mito narra una realidad que funge como modelo ejemplar que hay que repetir"9. En la perspectiva de Pannenberg, pues, lo propio del mito no es ser una explicación precientílica de lo real, sino en ser una explicación de lo real - del hombre y la sociedad- desde los orígenes. Y esto es de graves consecuencias, porque si lo fundamental es el origen, "la esencia del hombre, su salvación, el modelo de hombre, ya están dados en el origen. La verdad del mundo y del hombre se han dado ya en el principio y el hombre es por esencia un ser orientado al pasado"10.

Si lo verdadero está en el origen, de lo que se trata es de volver a ese origen, 
de recuperarlo. De lo que se trata es de volver a esa "verdad original", es decir, de volver al pasado. "La historia es una degeneración del origen, y la verdad de un momento histórico sólo puede aspirar a re-crear cúlticamente el origen, como por ejemplo en los ritos de la fertilidad, que intentan recrear en el liempo la verdad original de la fertilidad de los dioses"ll. Por ello es que dice Pannenberg que lo propio del pensamiento mútico es su contraposición al pensamiento utópico, es decir, al pensamiento abierto al futuro.

"Así vivía el hombre mítico de espaldas al futuro; su mirada se anclaba en el tiempo primigenio del mito y su esfuerzo estaba dirigido a permanecer lo más cercanamente posible a esas formas originarias de toda verdadera vida... Esto corresponde sorprendentemente a una concepción de la verdad, según la cual la verdad yace en el pasado y para la cual del futuro sólo es importante lo que esté de acuerdo con la antigua verdad" 12 .

Como podemos notar, según Pannenberg, "lo típico del mito es una comprensión del hombre a partir del pasado, mas exactamente, a partir de un origen divino fundamentante del presente. En la historia no puede acaecer nada nuevo e importante y el fin de la historia, bien sea en movimientos cíclicos bien sea en un fin absoluto, sólo puede consistir en volver a los orígenes. La escatología, es decir, la verdad del fin coincide con la protologia, es decir, la verdad del origen"13.

c) La superación del mito propuesta por Pannenberg. Pannenberg, al igual que Bultmann, quiere ofrecer una alternativa al mito. Para Bultmann, ya lo vimos, la alternativa al mito es el pensamiento maduro, es decir, el pensamiento cientifico. Pannenberg es mucho más radical que Bultmann en su propuesta. Por ejemplo, el pensamiento filosofico griego - en la propuesta de Bultmann- sería una superación del pensamiento mitológico, ya que sería la superación de una mentalidad pre-científica. Pero en la propuesta de Pannenberg, la misma filosoffa griega sería una filosofía mitológica, ya que "la filosofía griega, a pesar de hacerse científica, no supera una concepción de la verdad a partir del origen" 14 .

"En los diversos sistemas filos6ficos griegos este origen es concebido de maneras muy diversas, pero la idea fundamental permanece la misma... Dios es el que ha actuado en el origen. Ese origen puede ser entendido cronologicamente, como una 'creacion' en que Dios ha impuesto sus leyes al mundo, o como un origen lógico. Pero lo importante es son las implicaciones de esta concepción de Dios como dios del origen: la verdad sigue permaneciendo en el origen"IS.

En resumen: "el pensamiento griego, por tanto, a pesar de hacerse cientifico, no supera lo que según Pannenberg es la esencia del mito: la comprensión a partir del origen, vivir de espaldas al futuro y no esperar de él más que que la 
integración en el orden eterno del cosmos"16. Pero si la superación radical del mito no proviene del pensamiento cientffico, $i$ de donde proviene entonces?

Para Pannenberg esa superación radical del mito proviene del pensamiento bíblico. Porque en el pensamiento biblico lo fundamental no son los orígenes, sino el futuro. Y esta experiencia del futuro como lo esencial nace de la "comprensión de la realidad como historia" (J. Sobrino) que tiene el pueblo de Israel.

"Dios aparece en Israel, no en primera línea como origen del mundo, de los procesos normales que se repiten, sino como el Dios vivo que una y otra vez realiza lo nuevo; la realidad no es la naturaleza que gira sobre sI misma y que sólo pueda a aspirar a reproducir el pasado, sino la historia que avanza hacia lo realmente nuevo; la aclitud antropológica fundamental no consiste en mirar al pasado para imitarlo, sino al futuro para recibirlo y hacerlo. La esperanza entra en la historia como caracteristica fundamental del hombre"17.

Esto hace del pensamiento brblico un pensamiento antimítico y desmitificante (J. Sobrino). Ciertamente, "no en el sentido de Bultmann, pues es obvio que Israel explica muchas de sus conpceciones en esquemas pre-científicos, pero sf en el sentido de Pannenberg, es decir, en cuanto que la experiencia originaria de Israel no es vivir de un origen fundamentante, que hubiera que repetir cúlticamente, sino del futuro de la promesa de Dios"18. En definitiva, Pannenberg piensa que sólo asumiendo la perspectiva brblica, antimítica, desmitificante y utópica, es posible superar radicalmente el pensamiento mítico, que nos ata al pasado y nos cierra al futuro.

\section{Configuración socio-cultural de occidente}

En el marco de la discusión Bultmann-Pannẹnberg, el mito aparece como algo que tiene que ser superado, ya sea mediante el desarrollo de un pensamiento cientffico o ya sea asumiendo una perspectiva utópica. La tesis de Bultmann no se sostiene si asumimos como válido el argumento de Pannenberg: los griegos si bien desarrollaron un pensamiento cientffico no por ello lograron desatarse de los lazos del mito. La tesis de este último es mucho más sugerente: la contraparte del mito no sería la ciencia, sino la utopla biblica. Sin embargo, esta tesis plantea un problema grave no de carácter teórico, sino de indole historica: ¿ha supuesto la imupción del cristianismo - como fenómeno social e historico- la anulación de formas míticas de pensamiento?

Pensamos que esta pregunta tiene que ser respondida en forma negativa: la irrupción socio-histórica ( $y$ cultural) del cristianismo no ha supuesto en el devenir histórico de occidente la superación del mito. Y lo que nos interesa aqur no es tanto hacer un recuento de los mitos que han acompañado al desarrollo socio-cultural de occidente, sino de las razones socio-culturales que explicarlan, 
desde nuestra perspectiva, la presencia del mito en dicho desarrollo.

Podemos ensayar una posible respuesta si hacemos una reflexión somera en torno a la siguiente pregunta: ¿cúales son los materiales culturales básicos que constituyen al mundo occidental? Pues bien, la configuración cultural de occidente se alimenta de tres grandes tradiciones: el pensamiento hebreo-semítico, la cultura griega y el cristianismo.

Precisamente, occidente nace de la confluencia de esas tres tradiciones socio-culturales, cada una de las cuales se remite a una herencia histórica particular: la primera gran cultura es la cultura hebreo-semítica recogida fundamentalmente en los libros del Antiguo Testamento (AT); la segunda gran tradición es la cultura griega, cuya expresión máxima es el pensamiento de Platón y Aristóteles; y la tercera gran tradición es la cultura cristiana, recogida en los escritos del $N T$, en la tradición patrística y la producción filosófico-teológica escolástica.

Justamente -como ya lo apuntamos- occidente es resultado de la confluencia y síntesis de estas tres grandes tradiciones culturales. Por lo tanto, es importante conocer la herencia dejada por cada una de ellas. Nosotros vamos a centrarnos en un momento fundamental de las tradiciones culturales semítica, griega y cristiana: vamos a reflexionar sobre la idea de hombre presente en cada una de esas tradiciones para intentar comprender, desde allf, qué es lo propio de occidente.

\subsection{La tradición hebreo-semítica}

Nos interesa la tradición cultural semf́tica recogida en los relatos del Antiguo Testamento, porque es la tradición que ha infuído directamente en lo que es occidente. Una pregunta obligada en este punto es la siguiente: ¿cuál es el marco histórico y social en el que se forja la concepcion semítica de hombre tal como aparece en el $A T$ ?

Pues bien, este marco histórico-social está configurado por una experiencia fundamental: la experiencia del "nomadismo". En efecto, Israel, que es el pueblo creador de la cultura bíblica veterotestamentaria, es un pueblo nómada. Y elabora toda su visión de la realidad humana y divina desde esa experiencia vital, que es también una experiencia social e histórica.

La idea de Dios que se forja es la de un Dios absolutamente libre y creador de todo lo existente, que se "revela" históricamente, es decir, un Dios que se revela en aquellos acontecimientos en los que intervienen los hombres como grupos y colectividades. Concretamente, se forja la idea de un Dios que se revela privilegiadamente en los procesos históricos de liberación. El Exodo es, en este sentido, la experiencia fundamental de fe del pueblo de Israel. 
El hombre, por su parte, no se entiende si no es por su referencia a Dios: Dios lo creó a su imagen y semejanza y, por ello, está llamado a abedecerle y a realizar los designios de su creador. Y el mandato primero y radical de Dios a los hombres es el mandato de construir una historia, es decir, el mandato a lanzarse al futuro: justamente la promesa fundamental de Dios al pueblo de Israel es que sólo le podrán conocer como su Dios en la medida que avancen hacia ese futuro histórico $(G n 12,1-9)$.

Ahora bien, esa historia que Dios llama a construir a los hombres - a través de Israel- es una historia de salvación. Es decir, una historia en la que no habrán de existir la opresión, la esclavitud y el sometimiento de unos hombres por olos. Por ello, donde se dan procesos historicos de opresion, como la esclavitud de Israel en Egipto, Dios se revela liberando a su pueblo, es decir, Dios se revela como un Dios liberador. Y Dios quiere que la historia sea una historia de salvación simple y sencillamente porque los hombres están hechos a imagen y semejanza suya, y por lo tanto cuando se dan la injusticia y la opresión es Dios mismo el que es oprimido y esclavizado. A Dios le duele en su propia carne que sus creaturas sufran; asimismo, a Dios, según la mentalidad brblica, le elegra que el hombre sea feliz.

Pero, ya lo hemos señalado, la felicidad humana se ha de alanzar en la historia por el propio esfuerzo humano. Y ello, porque Dios asi lo quiere: Dios ha hecho al hombre un ser libre. Y su libertad la ejerce el hombre - tiene que ejercerla - creando una historia, produciendo mediante su propia trabajo aquellas condiciones sociales e históricas que hagan posible esa creación suprema de Dios que es su propia vida. Creando esa historia, transformando la realidad que le rodea y transformándose a sí mismo, es como el hombre va concretando la voluntad de Dios en la historia: es en la historia así entendida, como creación humana nunca acabada, donde Dios se revela al hombre como su salvador y liberador

Pues bien, es a la luz de esa visión de lo que es la realidad historica como historia de salvación, que Israel elabora su concepción de lo que es la realidad humana. Para el pensamiento brblico, ya lo dijimos, Dios ha creado la totalidad de lo existente. Por consiguiente, Dios es el que ha creado al hombre. Pero el hombre, como cratura de Dios que es, es una realidad unitaria, inlegral. Es decir, Dios cré un hombre real. Y real es, para el hebreo-semita, la unidad de lo sensible y lo espiritual. Dicho de otra forma, lo sensible es lo carnal o corporal, mientras que lo espiritual es la Palabra de Dios que desde los orígenes se ha hecho realidad en lo sensible-camal.

De esta forma, no hay una concepción dualista de lo que es el espíritu y la sensibilidad, o de lo que es el alma y la carne. En la antropología bíblica, el espíritu no es real sin la sensibilidad y la sensibilidad, la carne, no es real sin el espíritu. El hombre es la unidad total de cuerpo y espíritu o, a la inversa, la 
unidad de espíritu y cuerpo. Incluso siendo más rigurosos en el modo de definir lo que es el hombre para el hebreo-semita, tenemos que decir que el hombre es un espíritu-corpóreo o un cuerpo-espiritualizado.

En resumen: la idea de hombre que tiene el hebreo-semila no es una idea dualista; en el hombre no hay dos compuestos, uno material y otro espiritual. El hombre es una realidad total y unitaria: es "alma-corpórea" o "corporeidad-anímica". (X. Zubiri). Por ello, de lo que se trata en la historia de la salvación es que el hombre se realice totalmente; de lo que se trata es que el hombre se realice carnal y espiritualmente. Y el hombre sólo se realiza plenamente en la historia: por ello, la historia de la salvación no es real sin una salvación en la historia (I. Ellacurla).

\subsection{La tradición griega}

En la cultura griega de los siglos V-I a.c. se elabora una idea concreta de lo que es el hombre, radicalmente distinta de la concepción hebreo-semítica. Esta elaboración se debe, fundamentalmente, a Platón y Aristóteles. Una pregunta obligada es la siguiente: ¿cuál es el marco de referencia vital desde el que se elabora la antropología y la filosofía griega? Pues bien, si para los semitas lo fundamental es su relación con lo histórico, la experiencia fundamental de los griegos es su relación con la naturaleza.

En efecto, la mirada del griego está orientada hacia el 'cosmos', hacia el 'universo'. Y dentro de ese cosmos, dentro de ese orden universal, al hombre le corresponde un punto axial: el hombre es el centro que unifica la totalidad de ese cosmos. Es decir, el hombre es un "micro-cosmos" (E. Coreth). Y ello es así, porque en el hombre se reunen todos lo grados de ser y de vida, que en él forman una unidad superior que refleja la unidad del universo. En este sentido, el hombre es una parte de la naturaleza y como todas las cosas naturales pertenece al campo de lo físico-natural.

Ahora bien, el hombre tiene algo que le caracteriza y constituye su propia esencia: el hombre tiene alma. Por tanto, la dignidad del hombre se sitúa en lo espiritual, y lo material y corporal son algo necesariamente negativo. Esta concepción aparece claramente formulada en Platón (428-348 o 347). Para Platón hay un dualismo radical entre espiritu y materia, entre el alma espiritual y el cuerpo material. El cuerpo se presenta como la cárcel y la cadena del alma. Esta tiene que liberarse de los lazos que la vinculan al mundo material para poder retomar así a su existencia real que es puramente espiritual.

Esto está ya planteado en la metafísica platónica. Según esta metafísica, la realidad está formada por dos grandes bloques: el bloque de las "cosas sensibles" y el bloque de las "ideas inteligibles". Entre ambos bloques hay relación: 
el orden de lo sensible es un "reflejo" deformado de lo que es el orden de lo inteligible. Por tanto, la vardadera realidad es la realidad de las ideas inteligibles, que es una realidad perfecta, inmutable y eterna. De esto se sigue que el cuerpo, es decir, lo sensible en el hombre, la carne, es para Platón algo negativo; lo único positivo es el alma o el espíritu, que es lo que el hombre tiene, por participación, del mundo inteligible.

El hombre está atravesado por esas dos dimensiones de la realidad. Pero en el fondo la única verdadera realidad del hombre es la realidad de lo espiritual. Por consiguiente, de lo que se trata en Platón es de "liberar" al espíritu de la cárcel corporal. Sólo liberado del cuerpo puede el espíritu acceder al orden de las ideas inteligibles, que es el orden de la suprema y verdadera realidad. Esto sucede felizmente en la muerte.

Aristóteles (384-322) intenta superar el dualismo platónico entre cuerpo y alma. De acuerdo con Aristóteles las cosas naturales son un compuesto de materia y forma (hyle y morphé). La materia, por una parte, es el material del cual están hechas las cosas, mientras que la forma es lo que configura a la materia; la forma es la idea, el eidos de la cosa. Es decir, las ideas no están separadas de las cosas sensibles, sino que están articuladas con lo material.

En el caso del hombre, el alma es la forma del cuerpo. El alma (psiche) es el principio esencial que configura internamente a la materia convirtiéndola en cuerpo humano. Pero la materia juega un papel importante en este proceso ya que es el medio potencial que recibe la determinación por la forma esencial y le confiere al cuerpo humano su positiva individualidad, determinada en el espacio y en el tiempo. Entonces, en Aristóteles el hombre es una realidad unitaria: es la unidad de alma (forma) y cuerpo (materia). Con esta formulación Aristóteles intenta superar el dualismo antropológico de Plalón.

Pero la perspectiva aristotélica no es tan radical como parece. Porque al igual que en Platón, para Aristóteles lo fundamental en el hombre sigue siendo el elemento espiritual. Sólo que para él este elemento espiritual es la razón, es decir, la facultad de conocimiento intelectual. Lo corporal, lo sensible queda siempre en segundo plano. El hombre, en el fondo, sigue siendo un compuesto de dos elementos: el alma y el cuerpo, y el fundamental sigue siendo el primero de ellos.

De esta forma, Aristóteles cae en un reduccionismo intelectualista, ya que termina diciéndonos que el hombre es un ser que se define por su facultad de conocer racionalmente la realidad. Esa facultad de conocer apunta hacia lo necesario y eterno. En Platón lo necesario y eterno es el orden de las ideas inteligibles. En Aristóteles es el orden de las formas (ideas platónicas), presentes y actuantes en las cosas naturales. 
La razón humana interesa no en cuanto razón subjetiva, es decir, no en cuanto razón de un sujeto, sino en cuanto razón objetiva, es decir, en cuanto que es el "reflejo" lógico de la estructura también lógica de la realidad. Justamente, lo que distingue al hombre de los animales es su forma específica: la razón, que es capaz de coincidir con la estructura de las cosas. Aún en el caso del hombre, pues, el punto de referencia es lo natural-objetivo: el hombre está inserto en el cosmos y está sometido a su misma legalidad objetiva.

En resumen, el interés del pensamiento helénico es lo eterno y necesario, es decir, lo que siempre se repite. Lo que de nuevo hay en la vida de los hombres, no le interesa, ya que no es objeto de auténtico conocimiento cient/fico o filosofico. Es decir, al griego no le interesa la realidad histórica. En este sentido, el griego está cerrado al futuro y a la utopía, porque está aferrado a lo que siempre se repite, es decir, a lo que Nietzche llamo, el "eterno retorno". En este contexto, el hombre es una realidad natural entre otras, carente de protagonismo histórico y aferrado a ese orden cósmico que gira siempre sobre sí mismo.

\subsection{La tradición cristiana}

El cristianismo surge en un contexto histórico greco-romano. Es decir, surge en un mundo dominado política y económicamente por el imperio romano, pero que, a la vez, está dominado culturalmente por las tradiciones griegas. Es ante este mundo cultural, político y económico que se confrontará el cristianismo y ante el cual tendrá que irse definiendo, tanto para conservar su identidad como también para seguir siendo una tradición viva y actual.

La tradición cristiana es el resultado de una síntesis: la sintesis del pensamiento bíblico (hebreo-semita) y del pensamiento helénico. Esta síntesis se elabora en el cristanismo de los primeros siglos (siglos I-VI), se consolida durante alta edad media (siglos VI-XIII) y entra en crisis durante la baja edad media (siglos XIII-XVI). Lo más original de la antropología cristiana, es decir, de la concepción cristiana del hombre, se desarrolla durante los primeros siglos de cristianismo. Por ello, nos centraremos en los aportes de este cristianismo originario. En esta síntesis inicial entre pensamiento hebreo-semita y pensamiento helénico, este último es sometido a una depuración crítica, de forma tal que de él no llegan a asumirse contenidos fundamentales, sino sólo algunos de sus esquemas mentales (racionales y filosoficos), necesarios para la expansión de la fe cristiana. Los contenidos fundamentales del cristianismo tienen sus raíces en la tradición brblica hebreo-semf́tica. En efecto, el cristianismo primitivo introduce en el naciente mundo occidental tres categorfas fundamentales para la comprensión del hombre: historia, humanidad y libertad.

Como ya vimos, la noción de historia carece de importancia para los griegos, ya que para ellos lo único real es lo natural. Pues bien, para el cristiano lo 
fundarnental es lo histórico: la revelación definitiva de Dios acontece en la vida histórica de Jesús de Nazaret, en su crucifixión y en su resurrección. Por tanto, lo histórico se convierte en lo más real de la realidad, porque es justamente el lugar que Dios ha escogido no sólo para revelarse, sino para encarnarse y padecer a la manera humana. Lo histórico es, pues, lo más denso de la realidad, ya que es el lugar donde acontece la manifestación radical y definitiva de Dios.

Si ello es así, la realidad y la realización del hombre se juega en la historia. El horizonte de la vida humana habrá de configurarse en el horizonte abierto por la vida histórica de Jesús de Nazaret. En definitiva, la vida humana habrá de configurarse - para el cristiano- en el seguimiento histórico de Jesús. Y lo más propio de este seguimiento será el sacrificio por los demás, la renuncia, el compromiso, el confliclo y la persecución.

En segundo lugar, junto con la noción de historia, el cristianismo introduce otra categoría fundamental para la comprensión del hombre: la categoría de humanidad. Para el griego no existe la idea de humanidad. Para el griego, sólo los griegos son hombres; los demás - los esclavos y los metecos- son algo menos que animales.

Pues bien, el cristianismo produce una revolución en el modo de entender a la humanidad y al hombre: para el cristiano todos los hombres son seres humanos, y por tanto todos los hombres son iguales. Llevada esta idea al plano económico, político y social inmediatamente se hace evidente su carga subversiva. Porque si todos los hombres son iguales, no tiene porque haber ricos y pobres, opresores y oprimidos, amos y esclavos. Lo grave, sin embargo, no está en que se anuncie la igualdad entre los hombres desde la desigualdad imperante, sino en que esa denuncia y ese anuncio se hacen desde el mismo Dios.

Es decir, Dios al hacerse hombre carga con el pecado de la humanidad, carga con la injusticia y la opresión vigentes en la sociedad. Más aún, carga con la injusticia y la opresión ocupando el lugar del pobre y del oprimido: $y$ al hacerlo, denuncia lo establecido y anuncia una nueva realidad, una buena nueva (=Evangelio), en la que los pobres dejarán de serlo porque se vivirá en plena justicia, igualdad y freternidad. Entonces, al ocupar el lugar del pobre Dios opta por él. Por consiguiente ofender al pobre, hacer que el pobre siga siendo pobre, es ofender a Dios.

En esto consiste la gravedad y radicalidad del mensaje cristiano; se condena la desigualdad entre los hombres y se anuncia la justicia y la igualdad desde el mismo Dios, del cual los hombres están hechos a imagen y semejanza. El poder religioso, político y económico judío-romano se ve cuestionado en sus fundamentos por este humanismo y reacciona con violencia, siendo su primera víctima el mismo Jesús de Nazaret. En efecto: si la vida de Jesús de Nazaret es el testimonio último de lo que Dios quiere para los hombres: que haya vida para el 
pobre, amor, justicia e igualdad, su muerte, provocada por los poderes de este mundo, es la prueba máxima de la radicalidad de su denuncia y de su anuncio de la buena nueva del reino.

La iglesia cristiana de los primeros siglos asume esta radicalidad de Jesús, lo cual hace que no sea bien vista por el poder establecido; más aún, el poder establecido reacciona violentamente; no es casual que los primeros mártires cristianos surgen en esta época.

En resumen, el cristianismo introduce en occidente la idea de humanidad, es decir, la idea de la universalidad de la condición humana. Y si la humanidad es una, no están justificadas ni la opresión ni la esclavitud ni el sometimiento de unos hombres por otros. Estamos, entonces, ante un humanismo radical y genuino.

En tercer lugar, la tradición cristiana introduce en occidente la idea de que el hombre es una subjetividad libre, es decir, introduce la noción de libertad. Y que el hombre sea una subjetividad libre lo que quiere destacar es que el hombre es un ser de opción. Por tanto, que no es un ser sometido al determinismo natural o sometido al arbitrio de los dioses que no dejarían ningún margen para el ejercicio de la libertad humana.

Esto es así en los griegos, para quienes todo esı́́ regido por la necesidad de un destino prederminante: el fatum. Para los griegos, los hombres y los dioses están sometidos a una necesidad inexorable que es la que establece ya de antemano el destino feliz o infeliz de cada uno. Por lo tanto, para los griegos no hay auténtica libertad. No hay opción personal capaz de revertir el curso de los acontecimientos. Para el cristiano sí hay libertad: el hombre es esencialmente una creatura libre, que puede y que tiene que incidir en la configuración de su propio destino. El destino del hombre, pues, para el cristiano de los primeros siglos, no es algo prefijado de antemano, sino algo a realizar por el mismo hombre.

Y esto es así, ni más ni menos, porque Dios así lo quiere: Dios ha hecho del hombre un ser libre. Dios, como realidad absolutamente libre que es, ha creado a su imagen y semejanza al hombre, que es, por consiguiente, una realidad relativamente libre. El hombre ejercita su libertad creando una historia y humanizándose. En la medida que el hombre va historizando su libertad y se va humanizando, en esa medida va realizando la voluntad de Dios en la historia, es decir, va construyendo el Reino de Dios.

En sintesis, la herencia del cristianismo de los primeros siglos consiste en lo siguiente: primero, en haber enseñado que la realidad por exelencia es la realidad histórica; segundo, que la humanidad es una y que por tanto no están justificadas ni la opresión ni la esclavitud; y tercero, que la humanidad es una humanidad libre y que la historia es la concreción de esa libertad. Y, como trasfondo 
antropológico de todo ello, está la idea hebreo-semítica de que el hombre es una realidad integral, es decir, la unidad de cuerpo y alma, de materia y espíritu. Por tanto, quien crea la historia y se realiza (y se salva) en ella es la humanidad toda, en cuerpo y alma.

Hemos trazado las líneas más generales de lo que sería lo más original y novedoso del cristianismo en sus primeros cinco siglos por lo que loca a la comprensión de lo humano. Posteriormente, con el derrumbe de la sociedad greco-romana y el advenimiento del feudalismo (siglos VI-XVI), se producen cambios importantes en la tradición cristiana de los primeros siglos. Los más significativos son los siguientes: en primer lugar, el cristianismo va siendo asimilado poco a poco por el pensamiento helenista, lo cual hace que vaya perdiendo su propia identidad. En segundo lugar, se pierde el horizonte de lo histórico, volviendo a una concepción de tipo "naturalista". En tercer lugar, se desvaloriza la facultad de libertad de los hombres, haciéndolos dependientes de una presunta voluntad de Dios "manifestada" en la Iglesia. En cuerto lugar, se pierde el humanismo radical y combativo del cristianismo primitivo, ya que se justifica la existencia de hombres de segunda clase: los siervos. Y en quinto lugar, se cae en un dualismo antropológico de tipo platónico-aristolélico: la came es vista como lo negativo, mientras que el alma es vista como lo verdadero en el hombre.

Por tanto, la salvación no compete al hombre todo, sino a una parte de él: su alma. Y si la salvación compele al alma habrá que esperar hasta la "otra" vida para recibirla, ya que en ésta estamos presos de la carne. En este sentido, en el cristianismo que se desarrolla durante la edad media, se produce una vuelta hacia concepciones de tipo helenista, con lo cual se acaba traicionando lo mejor del cristianismo originario.

En definitiva, si el cristianismo de los primeros cinco siglos fue un cristianismo subversivo, el cristianismo posterior terminará siendo un cristianismo conservador y reaccionario. Este es el cristianismo que todavía pesa sobre nosotros: un cristianismo que no quiere la salvación total del hombre, es decir, que no quiere la salvación humana aquí y ahora, sino en la otra vida. Lo cual supone, en la práclica, dejar que los poderosos sigan produciendo vfctimas inocentes, es decir, supone dejar que la lógica de la dominación siga reinando y produciendo pobreza y hambre.

Para finalizar, hay que decir que con el derrumbe de la sociedad feudal (siglos XV-XVI) emergen de nuevo muchos de los valores antropológicos del cristianismo primitivo: la burguesía los hace suyos y se sirve de ellos para apuntalar su lucha y defender sus intereses. Pero aquf entramos ya en los albores de la modernidad. Antes de reflexionar sobre ello, apuntemos unas breves conclusiones que se imponen después de lo tratado hasta ahora.

Las conclusiones que queremos apuntar son las siguientes: a) que occidente 
no es "puramente" occidental, ya que en gran medida su identidad está configurada por culturas orientales; b) que la idea de hombre forjada en oriente (en la cultura hebreo-semítica) es más integral que la idea de hombre forjada por los griegos; c) que ambas antropologías confluyen en el cristianismo y desde ellas se configura la idea de hombre que tiene occidente; d) y que hay que rescatar lo mejor de la antropología cristiana de los primeros siglos, porque desde ella se puede pensar de manera más integral lo que es el hombre.

\section{Reflexión final: ¿por qué la modernidad es constitutivamente mítica?}

Con el derrumbe de la sociedad feudal adviene la modernidad. El progreso, la confianza en la razón, la búsqueda de la libertad y la emancipación,... son algunos de los valores proclamados por la burguesía en su enfrentamiento con los poderes estamentales. La defensa y proclamación de estos valores no es ajena a la herencia cristiana: la modernidad recupera y da vigencia a muchos de los supuestos cristianos, en especial a aquellos que hacen referencia al progreso y la utopía. Pero la modernidad también supone una recuperación del legado griego: la vuelta a la naturaleza para decifrar en ella los caracteres matemáticos en que están escritas sus leyes.

La modernidad —en esta perspectiva - constituye una nueva síntesis de las tradiciones culturales que alimentaron a occidente desde su fundación: la tradición cristiana ( $y$, a través de esta, la tradición hebreo-sernitica) y la tradición griega. Es decir, en la modernidad se entretejen una tradición naturalista y una tradición utópica, sin las cuales carecería de una identidad propia. La tensión entre estas dos tradiciones culturales es la que está en el origen de los dualismos (mito-ciencia, alma-cuerpo, salvaje-civilizado, tradición-modernidad, subdesarrollo-desarrollo, melancolía-metamorfosis...) que atraviesan consustancialmente al mundo moderno. Estamos ante un mundo cultural dual: un mundo que, al mismo tiempo, tiene como espejo el orden natural y que es movido por energías utópicas que miran hacia el futuro.

La modernidad es constitutivamente utópica. Pero es también constitutivamente mítica. Las energlas utópicas provienen de la herencia cristiana; su anclaje mítico proviene de la herencia griega. Ambas tradiciones socio-culturales no s6lo han alimentado el devenir de occidente en el pasado, sino que continúan nutriendo la búsqueda de identidad que la modernidad ha emprendido sobre sí misma. Para volver a la discución inicial entre Bultmann y Pannenberg, digamos que la ciencia moderna (la nueva ciencia) se supera (al igual que no lo hizo la ciencia de los griegos) al pensamiento mítico. La modernidad, pese a los grandes avances científico-técnicos, sigue viviendo de los mitos. Esto avalaría la tesis de Pannenberg en el sentido de que lo opuesto de lo mítico como lo pre-científico no es lo científico: en la modernidad, el mito no desparece con la ciencia. Pero 
tampoco es cierto que lo mítico desparezca con la utopla; por lo menos históricamente no es asf. En la historia de occidente el mito convive con la utopía y ambos constituyen los polos desde los cuales occidente y su modemidad buscan autocomprenderse.

Por consiguiente, no estamos de acuerdo con la afirmación de Victor Hugo que atribuye al cristianismo ese sentimiento que es "más que la gravedad y menos que la tristeza, la melancolía"19,y que R. Bartra sitúa como el punto de origen de la melancolfa modema20. Dicho de otro modo, en esta 6plica el mito en la modernidad tendría una matriz cristiana. AquI solo queremos apuntar que el repligue sobre sf mismo hacia la meditación que se advierte en el cristianismo de los primeros siglos no puede ser considerado sin más como "puramente" cristiano; no se pueden obviar los influjos neoplatónicos (y por tanto griegos) que ya desde la redacción de los textos más tardlos del Nuevo Testamento (es el caso del Evangelio de san Lucas y de las cartas de san Pablo) se hicieron sentir sobre las primeras comunidades cristianas. Ese repliegue sobre sí mismo hacia la meditación que se atribuye el cristianismo puede ser interpretado, a la manera cristiana, como una "entrega confiada" a la voluntad del Padre (voluntad que hay que descubrir en los acontecimientos), o puede ser interpetado, al modo griego, como un acto de reminscencia de un pasado al que hay que volver, $y$ del cual el presente es sólo un punto de retorno. Esa melancolía que se atribuye a los cristianos como un repligue hacia la meditación ante las desiluciones sociales y políticas serían — nos parece- más propias del estoicismo griego, desde donde se traspasaron al cristianismo.

\section{Notas}

1. Muchos autores presentan el relato del Génesis como un ejemplo del carácter mítico del Antiguo Testamenio (AT). Qué duda cabe que este documento está compuesto de múltiples relatos tomados de las tradiciones orales y escritas de la época; el Génesis es, en efecto, una narración con visibles rasgos mfticos, pero su función en el conjunto del $A T$ no es señalar el pasado al que hay que retornar (o al que se deberá necesariamente retomar), sino que cumple una función etiológica. Alcanzada la experiencia del Exodo (cuyo relato constituye uno de los texto más antiguos del $A T$, y no el Génesis como se podría a primera visla creer), hay que explicar los orfgenes de ese pueblo que se emancipó de la dominación egipcia: según los especialistas, esa es la función primordial del relato del génesis en el $A T$. Cfr. De Sivatte, R., Introducción al Antiguo Testamento. San Salvador, UCA/Ed., 1984.

2. Para esta aproximación a las tesis de Pannenberg y Bultmann nos remitimos al ensayo de J. Sobrino "Mito, antropología e historia en el pensamiento brblico". Estudios Centroamericanos (ECA), marzo-abril, 1974. pp. 171-187

3. Sobrino, J. Ib., p. 172

4. Sobrino, J., lb.

5. Sobrino, J., lb. p. 173

6. Sobrino, J., Ib. 
7. Pannenberg, W., Christentun und mythos. p. 9. Citado por Sobrino, J., lb. p. 74

8. Sobrino, J., lb.

9. Sobrino, J., Ib.

10. Sobrino, J., Ib.

11. Sobrino, J., lb.

12. Pannenberg, W., Was ist der mensch? p. 89. Citado por Sobrino, J., Ib. p. 174

13. Sobrino, J., Ib.

14. Sobrino, J., Ib.

15. Sobrino, J., Ib.

16. Sobrino, J., lb.

17. Sobrino, J., Ib. p. 176

18. Sobrino, J., Ib.

19. Hugo, V., Cromwell. Citado por Bartra, R., en La jaula de la melancolla. Identidad y metamorfosis del mexicano. México, Grijalbo, 1987. p. 231

20. Bartra, R., Ib. 